\title{
On a hexactinellid sponge aggregation at the Great Meteor seamount (North-east Atlantic)
}

\author{
JOANA R. XAVIER ${ }^{1}$, INÊS TOJEIRA ${ }^{2}$ AND ROB W.M. VAN SOEST ${ }^{3}$ \\ ${ }^{1}$ Centre for Geobiology and Department of Biology, University of Bergen, Thormøhlensgate 53A, 5006 Bergen, Norway, \\ ${ }^{2}$ EMEPC - Task Group for the Extension of the Continental Shelf, Rua Costa Pinto, no 165-2770-047 Paço de Arcos, \\ Portugal, ${ }^{3}$ Naturalis Biodiversity Center, Darwinweg 2, 2333 CR, Leiden, the Netherlands
}

\begin{abstract}
Hexactinellids or glass sponges constitute a predominantly deep-sea sponge group typically occurring at bathyal and abyssal depths. Some species form dense populations along the European and African continental slope but the distribution and extent of these populations remains ill known and the driving factors behind their occurrence poorly understood. Here we report an aggregation of the hexactinellid sponge Poliopogon amadou Thomson, 1878 at $\sim 2700 \mathrm{~m}$ depth on the Great Meteor seamount, a large seamount located southern of the Azores archipelago. A description of the species, along with scanning electron microscopy of its spicules, is provided.
\end{abstract}

Keywords: Porifera, Hexactinellida, glass sponges, vulnerable marine ecosystems, deep-sea, taxonomy, ecology

Submitted 13 February 2015; accepted 17 April 2015; first published online 21 July 2015

\section{INTRDDUCTION}

Glass sponges (Class Hexactinellida) constitute a predominantly deep-sea group, typically occurring at bathyal and abyssal depths (Leys et al., 2007), encompassing over 620 species worldwide (Van Soest et al., 2015). Although only 45 hexactinellid species are known to occur in the North-east Atlantic (Van Soest et al., 2015) some species are reported to form dense monospecific populations in some areas, e.g. Pheronema carpenteri (Thomson, 1869) on the Porcupine Seabight (Rice et al., 1990), on the Azores islands (Topsent, 1892) and the continental slope off Morocco (Barthel et al., 1996); Nodastrella asconemaoida Dohrmann, Göcke, Reed \& Janussen 2012 on the bathyal coral reefs of Rockall Bank (Van Soest et al., 2007 as Rossella nodastrella). Other hexactinellids are also common in the multispecific astrophorid grounds known as Ostur that occur in the boreo-Arctic region. Examples of such species are Asconema foliata (Fristedt, 1887) found in the Flemish Cap and Grand Banks (Murillo et al., 2012) and Schaudinnia rosea (Fristedt, 1887) on the Denmark Strait (Klitgaard \& Tendal, 2004). Various key ecological roles, e.g. substrate consolidation, benthopelagic coupling, and as hiding- and brooding places for associated fauna have been attributed to sponges in general (see a review in Bell, 2008). Apart from these, hexactinellid sponges in particular seem to further structure the deep-sea sediment, through spicule mats and stalks left upon their death, promoting the colonization by other invertebrates of this otherwise less suitable habitat, thus creating habitat islands (Bett \&

Corresponding author:

J.R. Xavier

Email: joana.xavier@bio.uib.no
Rice, 1992; Beaulieu, 2001). On account of their slow growth, high longevity and unknown reproductive and distribution patterns, deep-sea sponge aggregations are considered particularly vulnerable to anthropogenic activities such as bottom-fisheries, gas and oil exploration. For these reasons they are classified as vulnerable marine ecosystems of utmost conservation priority as expressed by the European Union Council Regulation no. 734/2008 and have been listed under the OSPAR convention list of threatened and/ or declining species and habitats (OSPAR commission, 2008). Poliopogon amadou Thomson, 1878 is a large pheronematid originally described from a specimen collected during the HMS Challenger expedition, at a depth of $2790 \mathrm{~m}$ southwest of the Canary islands. Some other records of the species have followed (Tabachnick \& Menshenina, 2002) but none indicating that this species formed dense aggregations. Here we report such an aggregation observed at $\sim 2700 \mathrm{~m}$ depth on the Great Meteor seamount.

\section{MATERIALS AND METHODS}

The seamounts south of the Azores were surveyed during a cruise organized in the scope of the Portuguese Continental Shelf Extension Programme (EMEPC/Açores/G3/2009 - EMEPCPortugal) on board the NRP 'Almirante Gago Coutinho' (Figure 1A). The Great Meteor seamount, located at $29^{\circ} 30^{\prime} \mathrm{N}$ $28^{\circ} 17^{\prime} \mathrm{W}$, is one of the largest seamounts of the North-east Atlantic. It steeply rises from more than $4500 \mathrm{~m}$ to less than $300 \mathrm{~m}$ and possesses a flattened summit of approximately $50 \mathrm{~km}$ in diameter (Figure $1 \mathrm{~B}$ ).

Samples were collected by the ROV 'Luso' (Figures $1 \mathrm{C} \&$ $2 \mathrm{~A}-\mathrm{C})$, sorted aboard and preserved in $96 \%$ ethanol until further processing. Identifications were made from thick 

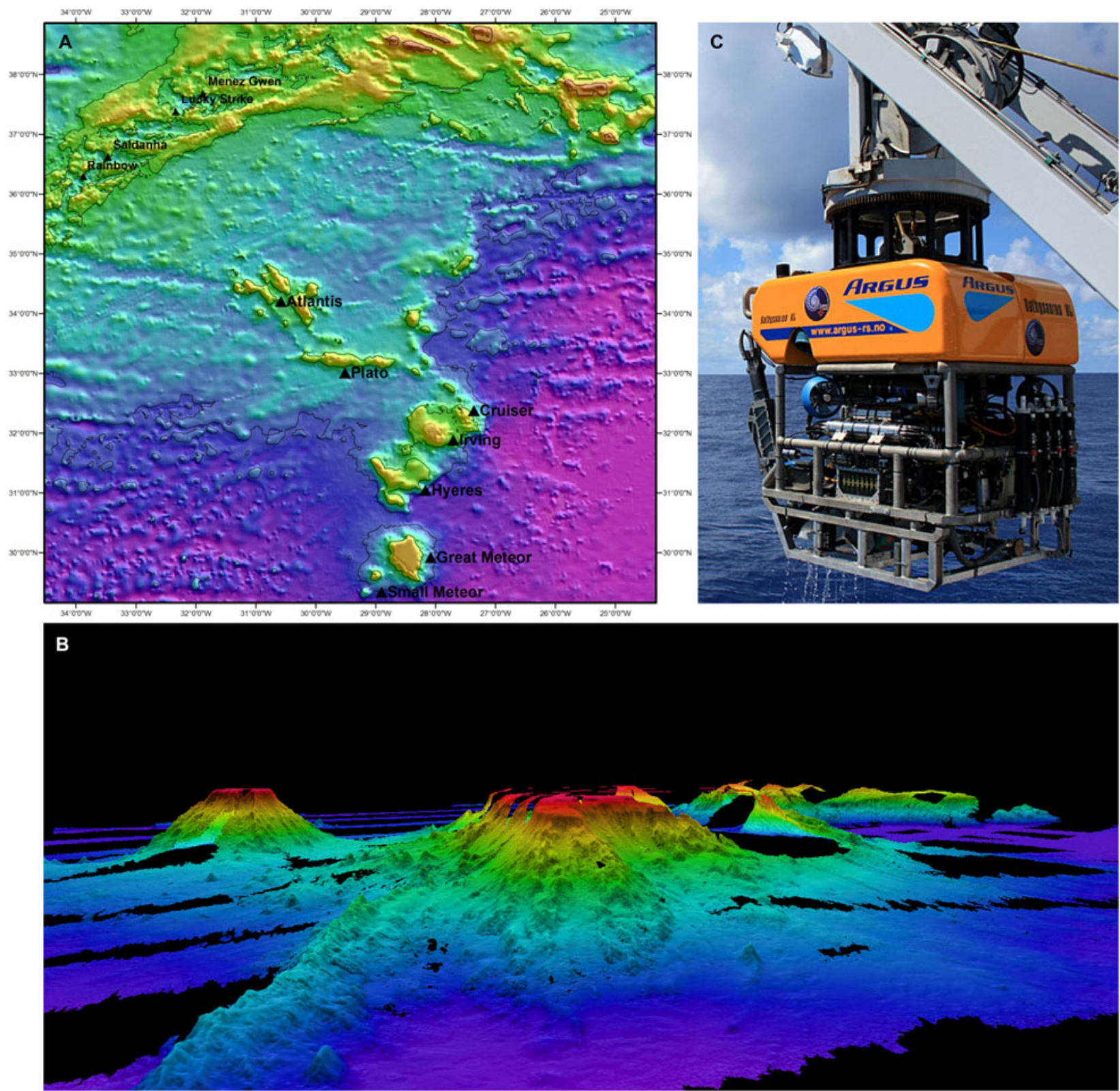

Fig. 1. Study area: (A) the seamounts located southern of the Azores archipelago; (B) the ROV 'Luso' (EMEPC-Portugal); (C) topographic contour of the Great Meteor seamount.

tissue sections mounted in Canada balsam. Spicules were dissociated by nitric acid boiling, washed, and examined at high magnification under scanning electron microscopy (SEM).

\section{SYSTEMATICS}

Class HEXACTINELLIDA Schmidt, 1870 Subclass AMPHIDISCOPHORA Schulze, 1886 Order AMPHIDISCOSIDA Schrammen, 1924 Family PHERONEMATIDAE Gray, 1870 Genus Poliopogon Thomson, 1878

\section{DIAGNOSIS}

Pheronematidae with a fan-like body in which the concave side represents the atrial cavity. Basalia are in relatively broad tufts and include some monaxones with clavate distal ends and two-toothed anchors. Choanosomal, hypodermal and hypoatrial spicules are pentactines, rarely stauractines and tauactines. Uncinates usually consist of only one type. Dermalia and atrialia are pinular pentactines and rare hexactines. Microscleres are amphidiscs (from one to three kinds) and combinations of microhexactines and pentactines (in some species also stauractines, diactines, monactines and spheres) (Tabachnick \& Menshenina, 2002).

Poliopogon amadou Thomson, 1878

EXAMINED MATERIAL

Lo9D12Bo3 (EMEPC/LUSO/2009 Expedition, Dive 12, Great Meteor seamount; coordinates: $29^{\circ} 30.5097^{\prime} \mathrm{N} 28^{\circ} 17.2138^{\prime} \mathrm{W}$; water depth: $2765 \mathrm{~m}$ ); coll. J.R. Xavier, 20 September 2009; Lo9D12Bo5(S2) (EMEPC/LUSO/2009 Expedition, Dive 12, Great Meteor seamount; coordinates: $29^{\circ} 30.4442^{\prime} \mathrm{N}$ $28^{\circ} 17.2385^{\prime} \mathrm{W}$; water depth: $2703 \mathrm{~m}$ ); coll. J.R. Xavier, 20 

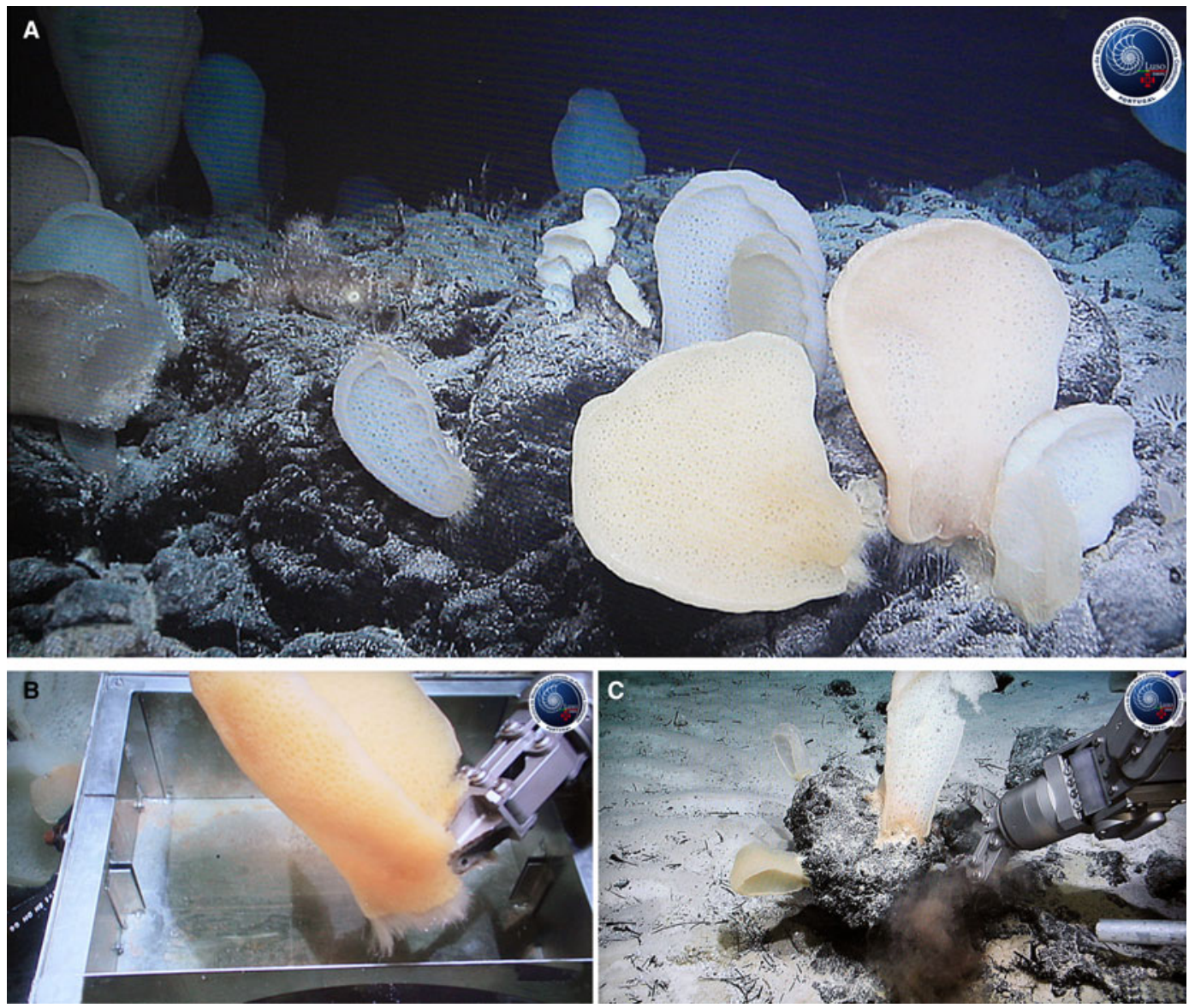

Fig. 2. In situ observations and sampling of P. amadou: (A) Large aggregation at $2700 \mathrm{~m}$ on the Great Meteor seamount; (B, C) sampling of specimens.

September 2009; Lo9D12Bo8 (EMEPC/LUSO/2009 Expedition, Dive 12, Great Meteor seamount; coordinates: $29^{\circ} 30.5090^{\prime} \mathrm{N} 28^{\circ} 17.2782^{\prime} \mathrm{W}$; water depth: $2675 \mathrm{~m}$ ); coll. J.R. Xavier, 20 September 2009; Lo9D13Bo1(S1) (EMEPC/ LUSO/2009 Expedition, Dive 13, Closs seamount; coordinates: $29^{\circ} 19.2800^{\prime} \mathrm{N} 29^{\circ} 07.8680^{\prime} \mathrm{W}$; water depth: $2761 \mathrm{~m}$ ); coll. J.R. Xavier, 21 September 2009.

\section{EXTERNAL MORPHOLOGY}

White to yellow thick-walled involute plate, fan or tongue shaped (Figure $3 \mathrm{~A}, \mathrm{~B}$ ). The largest specimen is fan shaped, measures $35 \mathrm{~cm}$ in length and $27 \mathrm{~cm}$ in width (Figure $3 \mathrm{~B}$ ). The thickness of the plate varies between $5-7 \mathrm{~cm}$ at its centre and becomes gradually thinner towards the margin. The atrial (concave) and dermal (convex) surfaces are covered by a fine quadrangular network of spicules (Figure ${ }_{3} \mathrm{C}$ ). A wide basal tuft of large spicules measuring approximately $9 \mathrm{~cm}$ in length enables its attachment to the rocky substrate (Figure $3 \mathrm{D}$ ). Upon preservation, specimens tinged the ethanol a dark fuchsia to dark purple and the sponge tissue turned purplish grey, as previously observed for this species by Moseley (1877).

\section{SKELETON}

Dermal and atrial skeleton comprise pinular pentactines with tangential rays slightly curved and sometimes uneven in size, measuring 70-87-112 $\times$ 4-5-10 $\mu \mathrm{m}$, and pinular rays measuring $172-265-448 \times 7-9-10 \mu \mathrm{m}$ (Figure $4 \mathrm{~B}$ ). Microscleres include macramphidiscs measuring 136-158-180 $\mu \mathrm{m}$ in length, with tuberculated shafts and different morphologies of the umbel $(48-54-60 \times 52-61-72 \mu \mathrm{m})$ (Figure $4 \mathrm{C}$ ), and smaller mesa- and micramphidiscs with spined shafts and slightly overlapping size ranges (Figure $4 \mathrm{D}$ ). Mesamphidiscs measure 68-102-140 $\mu \mathrm{m}$ in length with umbel measuring 23-37-52 $\mu \mathrm{m}$ (length) and 16-27-40 $\mu \mathrm{m}$ (width), whereas micramphidiscs measure 68-102-140 $\mu \mathrm{m}$ in length with umbel measuring 23-37-52 (length) and 16-27-40 $\mu \mathrm{m}$ (width). Microhexactines measure 68-88-112 $\times 3-4-5 \mu \mathrm{m}$ (Figure $4 \mathrm{E}$ ), whereas micropentactines (Figure $4 \mathrm{~F}$ ) and microstauractines measure $82-99-120 \times 3-5-5 \mu \mathrm{m}$ and $84-103-116 \times 2-3-4 \mu \mathrm{m}$, respectively.

Choanosomal skeleton is composed of large smooth pentactines measuring 320-436-480 × 18-21-24 $\mu \mathrm{m}$ (Figure $4 \mathrm{G}$ ), and three size-classes of uncinates. Most macrouncinates were broken but measure over $1.5 \mathrm{~mm}$ long (Figure $4 \mathrm{H}$ ) whereas mesouncinates measure $460-776-980 \times 2-3-4 \mu \mathrm{m}$. Some microuncinates were also found and these measure 50-118-216 $\times$ 1-1-2 $\mu \mathrm{m}$ (Figure $4 \mathrm{I}$ ). Basalia is composed of two-toothed anchors (Figure 4J) and monaxones (Figure ${ }_{4} \mathrm{~K}$ ) whereas the lateralia are sceptres (Figure $4 \mathrm{~L}$ ), all several mm long.

\section{REMARKS}

This species was originally illustrated and briefly described in Thomson (1878) and further described in Schulze (1887). Tabachnick \& Menshenina (2002) examined the holotype and provided a detailed description and measurements of 


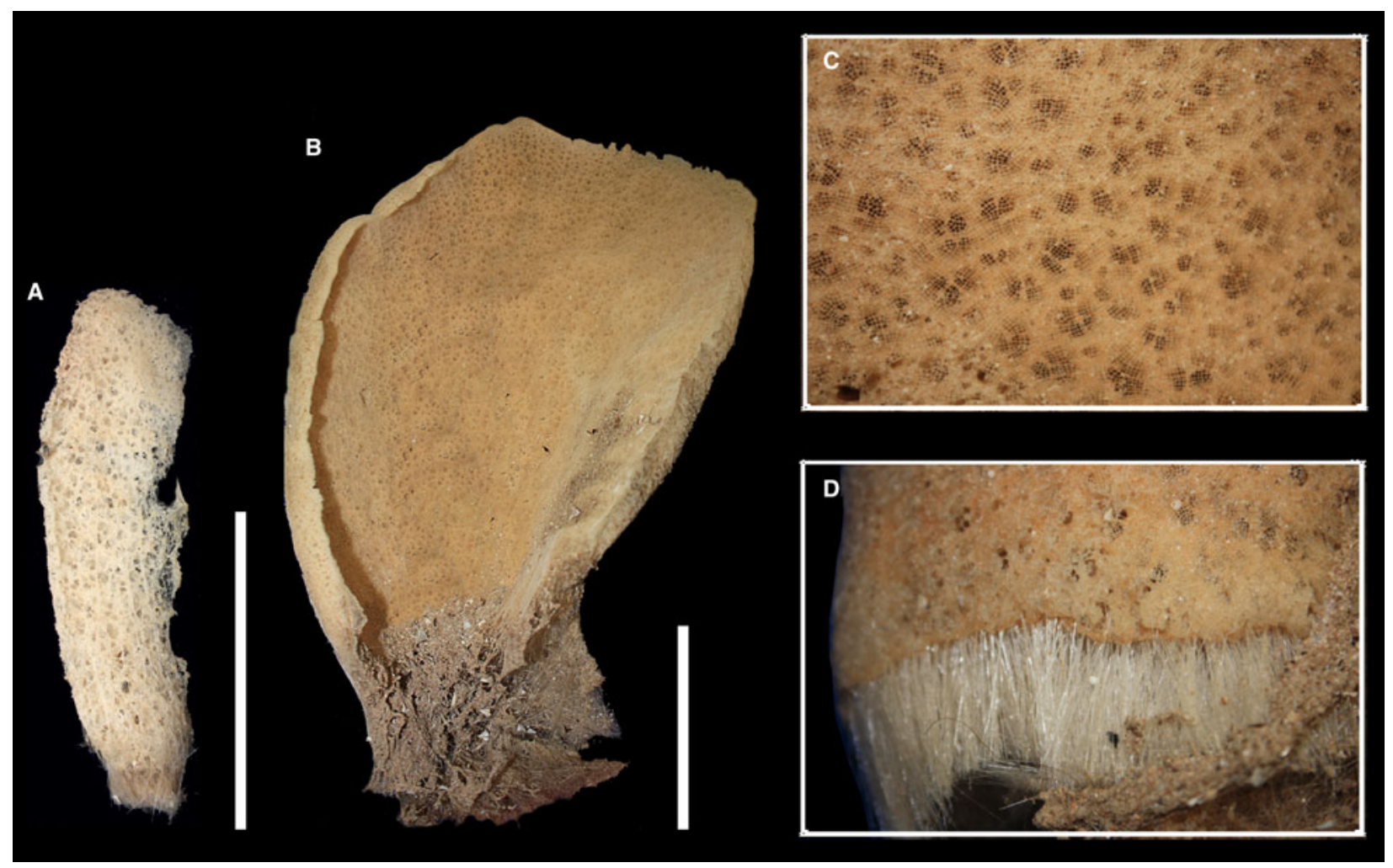

Fig. 3. Poliopogon amadou collected specimens: (A) dermal view of the tongue-shaped specimen collected on the Closs seamount; (B) atrial view of the large fan shaped specimen collected on the Great Meteor seamount; (C) detail of the atrial surface with its characteristic spicule network; (D) detail of the basal tissue-devoid tuft with long spicules.

spicules. Our specimens perfectly match their description despite some variability in spicule dimensions. However, they report the presence of only two size-classes of uncinates macro- and mesouncinates - whereas in our specimens we found also some, not very abundant, microuncinates. In our opinion these were either overlooked in the holotype or are simply a characteristic of this isolated population, thus bearing no specific taxonomic meaning.

\section{DISTRIBUTION}

The holotype of P. amadou (BMNH 1887.10.20.105) is a specimen collected from $2790 \mathrm{~m}$ depth southwest from the Canary Islands during the HMS Challenger expedition (station $3,25^{\circ} 24^{\prime} \mathrm{N} 20^{\circ} 14^{\prime} \mathrm{W}$ ). This species has also been reported from westernmost areas on the Mid-Atlantic Ridge between 2480-4022 $\mathrm{m}$ depth (Tabachnick \& Menshenina, 2002). In this study four specimens were collected from seamounts located south of the Azores archipelago: three specimens at the Great Meteor seamount between 2675-2765 m depth and one specimen at the Closs seamount at $2761 \mathrm{~m}$ depth.

\section{DISCUSSIDN}

Poliopogon amadou is the only species of this genus to occur in the Atlantic, all other occurring either in New Caledonia (P. claviculus, P. micropentactinus and $P$. zonecus) or in Central Polynesia (P. maitai) at depths between 697 and 4270 m (Tabachnick, 1988; Tabachnick \& Lévi, 2000).
During the campaign that led to the present study several isolated specimens were seen, but in one of the Great Meteor seamount stations (Lo9D12) a large number of specimens, of various sizes, was observed on a rocky outcrop (Figure 2A). Surprisingly, specimens were always found attached with their basal tuft to hard rocky substrate (Figure $2 \mathrm{C}$ ) and never to the surrounding sandy substrate.

Due to data limitation (no videos available) it is beyond the scope of the present article to provide estimates of population size. However, from the pictures taken and observations made during the ROV dives it is possible to describe some of its characteristics. The population exhibited a very patchy distribution with local densities attaining up to 5 ind. $\mathrm{m}^{-2}$. The same pattern has been found in Pheronema carpenteri populations located on the Porcupine Seabight where densities varied from 0.8 to 5 ind. $\mathrm{m}^{-2}$ (Rice et al., 1990), and off the Moroccan slope where densities ranged from 0.17 ind. $\mathrm{m}^{-2}$ over $100 \mathrm{~m}$ transects to 6 ind. $\mathrm{m}^{-2}$ in single pictures covering $1.5 \mathrm{~m}^{2}$ (Barthel et al., 1996); and in Nodastrella asconemaoida in the Rockall Bank where densities varied from 0.66 to 6 ind. $\mathrm{m}^{-2}$ (Van Soest et al., 2007). These highly patchy distributions are likely a combination between suitable ecological conditions and local recruitment.

The fact that specimens here examined were collected at a depth very similar to that of the holotype and of the other available records may indicate that this species forms bathymetrically constrained band-shaped populations as found in other ground-forming hexactinellids such as Pheronema carpenteri (Barthel et al., 1996). Rice et al. (1990) and White (2003) posited that the aggregation of Pheronema carpenteri in the Porcupine Seabight occurred close to, but not within, 


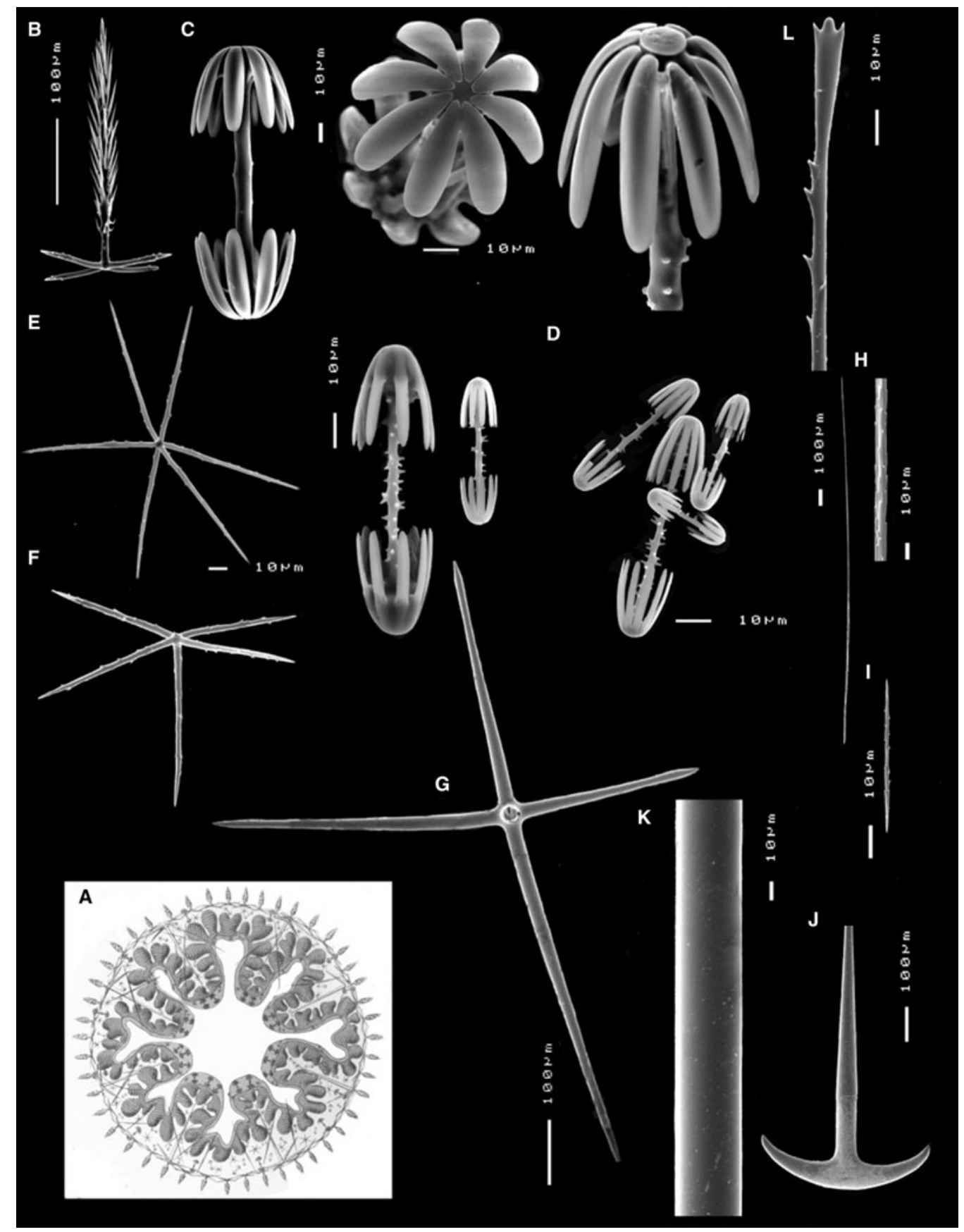

Fig. 4. Poliopogon amadou skeleton: (A) Illustration of a cross-section of P. amadou in Haeckel's 1898 'Kunstformen der natur'; (B) pinular pentactine; (C) macramphidiscs; (D) mesa- and micramphidiscs; (E) microhexactine; (F) micropentactine; (G) choanosomal pentactine; (H) macrouncinate; (I) microuncinate; (J) anchor; (K) monaxone; (L) sceptre.

areas of enhanced bottom tidal currents, i.e. in areas with increased deposition of organic particulate load.

Many small individuals were observed recruiting at the base of larger individuals, which indicates a stable population. The same was observed in a large population of Vazella pourtalesii, known as the Russian hat on the Scotian shelf in the North-west Atlantic (Fuller, 2011). Whether these young specimens are the result of asexual propagation or of sexual reproduction remains unclear, as both have been reported in different species (Leys et al., 2007). Lastly, no dead individuals were observed which could indicate a relatively young population.

\section{ACKNDWLEDGEMENTS}

The authors warmly thank the Task Group for the Extension of the Continental Shelf (EMEPC, Portugal), in particular Professor Manuel Pinto de Abreu, for the opportunity to participate in their numerous sampling campaigns. We are also indebted to all the crew members of the NRP Almirante Gago Coutinho and colleague researchers onboard for their seamanship. Elly Beglinger (NCB Naturalis), Luisa Ribeiro (EMEPC) and Raquel Pereira are thanked for providing help with the SEM and figures, whereas Marte Torkildsen 
(University of Bergen) is acknowledged for helpful discussions regarding skeletal variability in hexactinellids.

\section{FINANCIAL SUPPDRT}

This research was partly funded by a grant from the Global Census of the Marine Life on Seamounts (CenSeam) to J.R. Xavier and R.W.M. van Soest and by a postdoctoral grant (SFRH/BPD/62946/2009) from the Portuguese Science and Technology Foundation to J.R. Xavier.

\section{REFERENCES}

Barthel D., Tendal O.S. and Thiel H. (1996) A wandering population of the Hexactinellid sponge Pheronema carpenteri on the continenta slope off Morocco, Northwest Africa. P.S.Z.N. Marine Ecology 17 $603-616$

Beaulieu S.E. (2001) Life on glass houses: sponge stalk communities in the deep sea. Marine Biology 138, 803-817.

Bell J.J. (2008) The functional roles of marine sponges. Estuarine, Coastal and Shelf Science 79, 341-353.

Bett B.J. and Rice A.L. (1992) The influence of hexactinellid sponge (Pheronema carpenteri) spicules on the patchy distribution of macrobenthos in the Porcupine Seabight (bathyal NE Atlantic). Ophelia 36, $217-226$

Dohrmann M., Göcke C., Reed J. and Janussen D. (2012) Integrative taxonomy justifies a new genus, Nodastrella gen. nov., for North Atlantic "Rossella" species (Porifera: Hexactinellida: Rossellidae). Zootaxa 3383, 1-13.

Fristedt K. (1887) Sponges from the Atlantic and Arctic Oceans and the Behring Sea. Vega-Expeditionens Vetenskap. Iakttagelser (Nordenskiöld) 4, 401-471, pls 22-31.

Fuller S.D. (2011) Diversity of marine sponges in the Northwest Atlantic. PhD thesis. Dalhousie University, Halifax, 215 pp.

Gray J.E. (1870) Notes on anchoring sponges (in a letter to Mr. Moore). Annals and Magazine of Natural History (4) 6, 309-312.

Haeckel E. (1898) Kunstformen der Natur. Leipzig und Wien: Bibliographisches Institut, $400 \mathrm{pp}$.

Klitgaard A.B. and Tendal O.S. (2004) Distribution and species composition of mass occurrences of large-sized sponges in the Northeast Atlantic. Progress in Oceanography 61, 57-98.

Leys S.P., Mackie G.O. and Reiswig H.M. (2007) The biology of glass sponges. Advances in Marine Biology 52, 1-145.

Moseley H.N. (1877) On the colouring matters of various animals, and especially of deep-sea forms dredged by H.M.S. Challenger. Quarternary Journal Microscopical Society 17, 1-23.

Murillo F.J., Durán Muñoz P., Cristobo J., Ríos P., González C. Kenchington E. and Serrano A. (2012) Deep-sea sponge grounds of the Flemish Cap, Flemish Pass and the Grand Banks of Newfoundland (Northwest Atlantic Ocean): distribution and species composition. Marine Biology Research 8, 842-854.

OSPAR Commission (2008) Case Reports for the OSPAR list of threatened and/or declining species and habitats. Publication Number: 358/2008, $262 \mathrm{pp}$.

Rice A.L., Thurston M.H. and New A.L. (1990) Dense aggregations of a hexactinellid sponge, Pheronema carpenteri, in the Porcupine Seabight (northeast Atlantic Ocean), and possible causes. Progress in Oceanography 24, 179-196.

Schmidt O. (1870) Grundzüge einer Spongien-Fauna des atlantischen Gebietes. Leipzig: Wilhelm Engelmann, iii-iv, 1-88, pls I-VI.

Schrammen A. (1924) Die Kieselspongien der oberen Kreide von Nordwestdeutschland. III. und letzter Teil. Monographien zur Geologie und Paläontologie (1) Heft 2, 1-159, I-XVII.

Schulze F.E. (1886) Über den Bau und das System der Hexactinelliden. Abhandlungen der Königlichen Akademie der Wissenschaften zu Berlin (Physikalisch-Mathematisch Classe) 1886, 1-97.

Schulze F.E. (1887) Report on the Hexactinellida collected by H.M.S. 'Challenger' during the years 1873-1876. Report on the Scientific Results of the Voyage of H.M.S. 'Challenger', 1873-1876. Zoology 21 (Text): $1-514$

Tabachnick K.R. (1988) Hexactinellid sponges from the mountains of the West Pacific. In Shirshov P.P. (ed.) Structural and functional researches of the marine benthos. Moscow: Academy of Sciences of the USSR, pp. 49-64, 123.

Tabachnick K.R. and Lévi C. (2000) Porifera Hexactinellida: Amphidiscophora off New Caledonia. In Crosnier A. (ed.) Résultats des Campagnes MUSORSTOM, Volume 21. Paris: Mémoires du Muséum national d'Histoire naturelle (A, Zoologie), pp. 53-140. 184.

Tabachnick K.R. and Menshenina L.L. (2002) Family Pheronematidae. In Hooper J.N.A. and Van Soest R.W.M. (eds) Systema Porifera: a guide to the classification of sponges. New York, NY: Kluwer Academic/Plenum Publishers, pp. 1267-1280.

Thomson C.W. (1869) On Holtenia, a genus of vitreous sponges Philosophical Transactions of the Royal Society of London 159, $701-720$.

Thomson C.W. (1878) Voyage of the 'Challenger'. The Atlantic, Volume 1. London: Macmillan and Co., pp. 1-424.

Topsent E. (1892) Contribution à l'étude des Spongiaires de l'Atlantique Nord (Golfe de Gascogne, Terre-Neuve, Açores). Résultats des campagnes scientifiques accomplies par le Prince Albert I. Monaco 2, 1-165, pls I-XI

Van Soest R.W.M., Boury-Esnault N., Hooper J.N.A., Rützler K., de Voogd N.J., Alvarez de Glasby B., Hajdu E., Pisera A.B., Manconi R., Schoenberg C., Janussen D., Tabachnick K.R., Klautau M., Picton B., Kelly M., Vacelet J., Dohrmann M., Díaz M.-C. and Cárdenas P. (2015) World Porifera database. Available at http://www.marinespecies.org/porifera (Accessed on 12 January 2015).

Van Soest R.W.M., Van Duyl F.C., Maier C., Lavaleye M.S.S., Beglinger E.J. and Tabachnick K.R. (2007) Mass occurrence of Rossella nodastrella Topsent on bathyal coral reefs of Rockall Bank, W of Ireland (Lyssacinosida, Hexactinellida). In Custódio M.R., Lôbo-Hajdu G. Hajdu E. and Muricy G. (eds) Porifera research: biodiversity, innovation and sustainability. Série Livros 28. Rio de Janeiro: Museu Nacional, pp. $645-652$.

and

White M. (2003) Comparison of near seabed currents at two locations in the Porcupine Sea Bight - implications for benthic fauna. Journal of the Marine Biological Association of the United Kingdom 83, 683-686.

\section{Correspondence should be addressed to:}

J. R. Xavier

Centre for Geobiology and Department of Biology, University of Bergen, Thormøhlensgate 53A, Postbox 7803, N-5020 Bergen, Norway

email: joana.xavier@bio.uib.no 